\title{
Intra-Seasonal and Annual Variation of Aerosols and Their Radiative Impact in the Sahelian Zone of Burkina Faso
}

\author{
Bado Nébon 1,2*, Mamadou Simina Dramé2, Saidou Moustapha Sall², Korgo Bruno, \\ Demba Ndao Niang'ㄹ, Kieno P. Florent ${ }^{1}$, Bathiebo Dieudonné Joseph ${ }^{1}$ \\ ${ }^{1}$ Laboratoire d'Energies Thermiques Renouvelables (LETRE), Université Ouaga I Pr Joseph KI ZERBO, \\ Ouagadougou, Burkina Faso \\ ${ }^{2}$ Laboratoire de Physique de l'Atmosphère et de l'Océan Siméon-Fongang, Université Cheikh Anta DIOP, \\ Dakar, Sénégal \\ Email: *nebonbado@gmail.com
}

How to cite this paper: Nébon, B., Dramé, M.S., Sall, S.M., Bruno, K., Niang, D.N., Florent, K.P. and Joseph, B.D. (2019) Intra-Seasonal and Annual Variation of Aerosols and Their Radiative Impact in the Sahelian Zone of Burkina Faso. Atmospheric and Climate Sciences, 9, 62-74. https://doi.org/10.4236/acs.2019.91004

Received: October 22, 2018

Accepted: December 10, 2018

Published: December 13, 2018

Copyright $\odot 2019$ by authors and Scientific Research Publishing Inc. This work is licensed under the Creative Commons Attribution International License (CC BY 4.0).

http://creativecommons.org/licenses/by/4.0/

(c) (i) Open Access

\begin{abstract}
This paper deals with the characterization of aerosols in the Sahelian zone, particularly in Burkina Faso based on MODIS observations and in situ measurements of the AERONET network on the Ouagadougou site $\left(12.2^{\circ} \mathrm{N}\right.$, $\left.1.4^{\circ} \mathrm{W}\right)$. Thus, a seasonal spatial distribution of aerosols made over the period from 2001 to 2016 gives a very great variability of aerosols in Burkina Faso, whose maxima are encountered in Spring, characterized by winds from the North East. This seasonality of aerosols is also shown by the annual cycles of optical, radiative and microphysical parameters measured by AERONET between 1999 and 2006. Moreover, an analysis of these parameters shows the prevalence of mineral dusts characterized by low values of the Angstrom coefficient $\left(\alpha_{440-870}<0.5\right)$ associated with the maxima of AOT with high intensity in March. These dusts are confirmed by their scattering nature (SSA > 0.9 ) and the cooling noticed in the bottom of atmosphere (BOA) and at the top of the atmosphere (TOA). Also, the climatology of the volume size distribution of aerosols shows a very great variability of particles in terms of size influenced by the thin and coarse pattern where most sizes are between 1 and $10 \mu \mathrm{m}$.
\end{abstract}

\section{Keywords}

Aerosol, AERONET, MODIS, Microphysical and Optical Properties, Radiative Forcing

\section{Introduction}

Aerosols can be defined as suspensions in gaseous media of extremely thin par- 
ticles, solid or liquid with a low fall velocity [1]. To study the atmosphere, aerosols are generally considered as a population of particles of very variable size and morphology. Their very small shape is often associated with a sphere, making it possible to describe them easily by considering only one parameter, namely the diameter whose radius are generally between 0.001 and $100 \mu \mathrm{m}$ [2] [3]. In West Africa, particularly in the Sahel region, the aerosol population is heavily influenced by mineral dust because this area is close to the Sahara, recognized as the largest desert in the world and the first dust source [4] [5] [6] [7]. The African continent is also strongly marked by several bush fires all year round with high spatial and temporal variability [6]. This variability shows an activation of combustion in Central and Southern Africa from May, with an intensification in Summer, while bush fires in West Africa are intense notably in Winter [8] [9]. Thus, the African continent participates by $40 \%$ in the production of combustion particles and is one of the most important parts in the world where the various types of atmospheric aerosols are found [4] [10]. These aerosols have a huge impact on atmospheric visibility, affect the intensity of solar radiation and are source of several diseases such as meningitis at some periods, notably during the Harmattan [11]. In addition, several studies based on in situ measurements of the AERONET network, satellite observations and climate models make it possible to locate aerosols in West Africa during Spring and Summer [12] [13] [14] [15]. To this end, a study conducted by Senghor et al. [15] shows a strong seasonal variability of the dust layer in the West African zone. This made it possible to locate the aerosols around $3 \mathrm{~km}$ of altitude in Spring then between 3 and $5 \mathrm{~km}$ during Summer. However, in Winter the dust is more observed at the surface below $2 \mathrm{~km} \mathrm{[15]} \mathrm{[16].} \mathrm{This} \mathrm{distribution} \mathrm{of} \mathrm{particles} \mathrm{is} \mathrm{in} \mathrm{agreement} \mathrm{with} \mathrm{their}$ impact on the radiative balance of the climatic system observed on the surface, in the atmosphere and at the top of the atmosphere [17] [18] [19]. Despite all these studies, the characterization of aerosols remains problematic given their very variable optical, microphysical and radiative properties. To understand the distribution of aerosols over time and space in Burkina Faso, a climatological study is conducted based on the optical, microphysical and radiative properties from MODIS observations and in situ measurements of the AERONET network. This study aims to show the seasonal evolution and the high volume of mineral aerosols in this part of the Sahel.

\section{Data and Methodology}

\subsection{AERONET Network (Aerosol Robotic NETwork)}

For a better characterization of particles on the planet, a network of CIMEL photometers is developed on all over the globe: the global AERONET network (AErosol RObotic NETwork) initially established by NASA (National Aeronautics and Space Administration) in collaboration with the Laboratory of Atmospheric Optics (LOA) of the National Center for Scientific Research (CNRS). This network enables archiving and getting public access to data on the optical, mi- 
crophysical and radiative properties of aerosols in an almost real-time, continuously and for the long-term [20]. These are inversion results of various algorithms elaborated and improved over time by Dubovik et al. [21] [22] [23] [24]. AERONET aims at characterizing aerosol properties by constituting a permanently available database for aerosol climatology and the validation of satellite observations [25]. In addition, AERONET consists of partner networks such as PHOTONS (Operational Processing Photometry for Satellite Normalization) which deals with all photometers installed on the African and European continents, including CIMEL solar photometer, in Ouagadougou $\left(12.2^{\circ} \mathrm{N},-1.4^{\circ} \mathrm{E}\right)$.

\subsection{MODIS (MODerate Resolution Imaging Spectroradiometer)}

MODIS is a sensor transported by the TERRA satellites since December 1999 and Aqua in April 2002. TERRA sweeps the Earth surface from the North to the South around the equator in the morning around 10:30 am while Aqua occurs in the evening, around 10:30 am in an orbit oriented South-North of the Equator [26]. MODIS has 36 spectral bands that enable it to provide measurements on the atmosphere, the Earth and the ocean, 7 of which are used to study aerosols $(466,553,644,855,1243,1632$ and $2119 \mathrm{~nm})$. In addition, it uses different algorithms to invert aerosol properties on Earth [27] and on seas [28] where measurements are made with a spatial resolution ranging from 1 to $250 \mathrm{~km}$ and temporal from 1 to 2 days. For our study, we use MODIS-Terra Deep-Blue inversions at $550 \mathrm{~nm}$ and available on NASA's Giovanni site (https://giovanni.gsfc.nasa.gov/giovanni/). Indeed, the Deep Blue algorithm takes into account cloud masks, the aerosol model and the reflection of shiny surfaces [26] [29]. This makes it possible to eliminate contaminations due to the reflection of the shiny surfaces and to improve the qualified observations in level 2 in areas like the desert of the Sahara, the arid, semi-arid and urban regions where reflectivity is very significant [30].

\subsection{The Study Area}

Burkina Faso is a Sahelian country located in the heart of West Africa between latitudes $9^{\circ} 20$ and $15^{\circ}$ North and longitudes $5^{\circ} 30$ West and $2^{\circ} 30$ East. Its climate covers three climatic zones, including the Sahelian zone which covers the whole northern part, a larger Sudano-Sahelian zone extending from west to east and a more humid Sudanian zone to the south [31]. Note also that these areas are all marked by the same wind regime namely the monsoon which lasts approximately four (04) months from June to September and the Harmattan which extends from October to May. Indeed, in the West African zone, the dynamics of the atmosphere is strongly dependent on the monsoon flow which is a southwesterly wind and Harmattan marked by northeasterly winds. Because of its geographical location, Burkina Faso shares the same border with six states (Figure 1), starting by Mali and Niger in its northern part, which are largely affected by the Sahara Desert, followed by Côte d'Ivoire, Ghana, Togo and Benin in the South. 


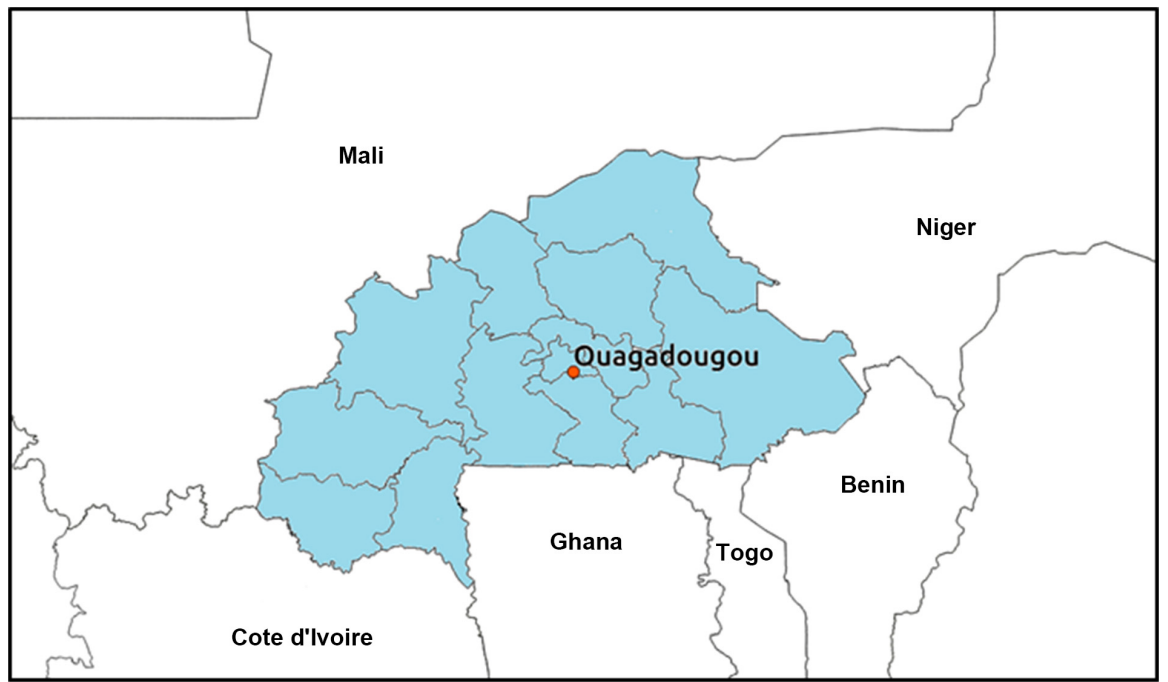

Figure 1. Presentation of Burkina Faso in blue color and geographical location of the Ouagadougou site $\left(12.20^{\circ} \mathrm{N},-1.40^{\circ} \mathrm{E}\right)$ in red dot.

\section{Results and Analysis}

\subsection{Spatial Distribution of Aerosols in Burkina Faso}

Figure 2 shows the seasonality of aerosols in Burkina Faso. It clearly indicates Spring (March-April-May) as the period of dust in Burkina Faso. The maximum of aerosols is observed in the northeastern part of the country. This is consistent with aerosol maxima in the sub-region, which main sources include the eastern part of Mauritania, the northwest of Mali and the eastern part of Niger towards the Bodéle depression in Chad [2] [32]. Also, the maxima of AOD in the East remove any doubt as to the influence of the Bodéle depression in the rise of the particles in Spring over most of the West African countries, notably Burkina Faso. Moreover, Spring in the Sahel is especially characterized by high temperatures due to the strong sunshine which can cause thermal depressions in the Sahara; hence the intense dust events. During the Summer (JJA), dust appears to be more dominant in the North, confirming the effect of sources located in the North-West of Mali and eastern Mauritania. It should also be remembered that during this rainy period, most of the dusty emissions are due to convective systems [33] and remote transportation but are less noticeable in the lower layer. In Autumn (SON), aerosols are intense towards the East and this is probably due to the impact of Bodéle and the activation of combustion sources in the South of the Gulf of Guinea. In addition, it should be noted that Autumn corresponds to the end of the rainy season in Burkina Faso, and entails the deposit of sediments following water evaporation, that is favorable to wind erosion [14]. However, Winter (DJF) is characterized by low AOD values with the maxima encountered further in the South. This distribution of aerosols reveals the significant presence of combustion particles from the Gulf of Guinea due to several biomass combustions over this period in West Africa [2] [8]. These particles get mixed with mineral dust carried by North-East winds. 
(a)-DJF

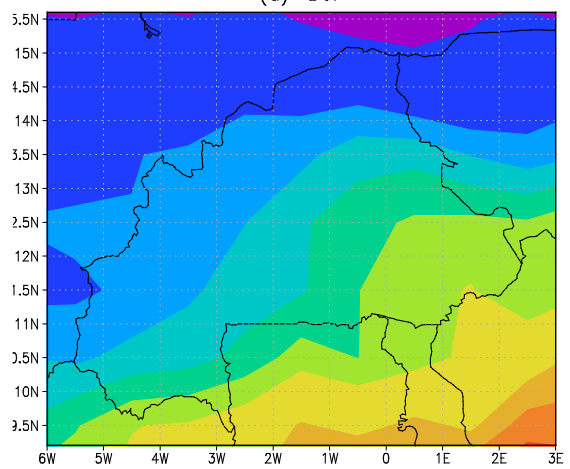

(c) -JJA

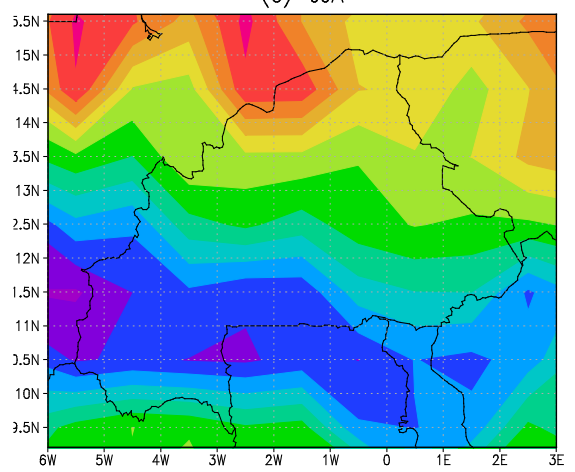

(b) - MAM

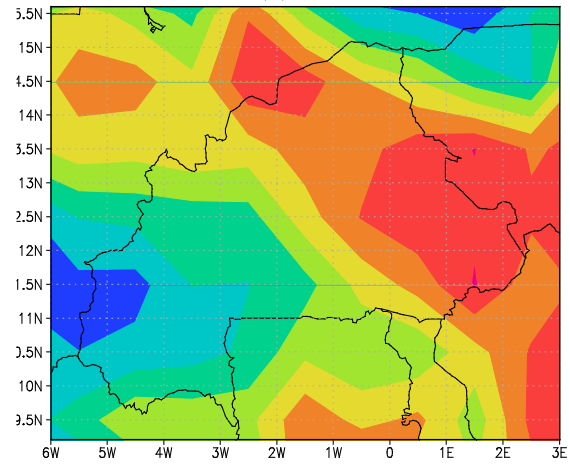

(d) - SON

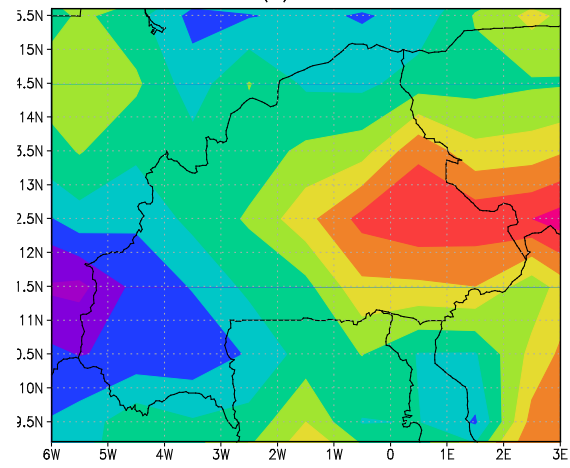

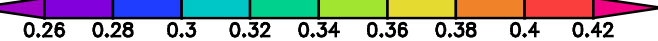

Figure 2. Inter-annual seasonal averages of the optical thickness between 2001 and 2016 of the MODIS sensor in Burkina Faso.

\subsection{Case of Aerosols on the Ouagadougou Site}

\subsubsection{Annual Cycles of the Optical Thickness and Angström Coefficient}

The annual cycles of the AOT (Figure 3) show the monthly inter-annual aerosol evolution on the Ouagadougou site from 1999 to 2006. This seasonality indicates a strong presence of aerosols during the dry period dominated by Harmattan winds which blow from January to June with a much higher intensity in March, then in May (Figure 3(a)). This is consistent with the maximum aerosols noticed in Burkina Faso in Spring (MAM). In addition, aerosols on the Ouagadougou site are heavily dominated by large particles (AOT-C) which impose aerosol climatology (Figure 3(b)) because of their large presence in the total AOT (AOT-T). This dust prevalence is clearly remarkable in March, April and May (Spring) characterized by low monthly average values of the Angstrom coefficient $\left(\alpha_{440-870}<0.3\right)$ calculated (Figure $\left.3(\mathrm{a})\right)$. This shows the huge influence of desert dust at this time of the year, which main sources are located in the Sahel and the North of the African continent. Despite the prevalence of mineral aerosols, the thin particles associated with AOT-F persist all year round but are embedded in the total AOT (AOT-T) by the largest ones associated with the AOT-C (Figure 3(b)). However, these particles follow the evolution of large particles and also occur from January to June followed by a decrease in AOT (AOT-F) from July to December with a slight increase in October. This similar 


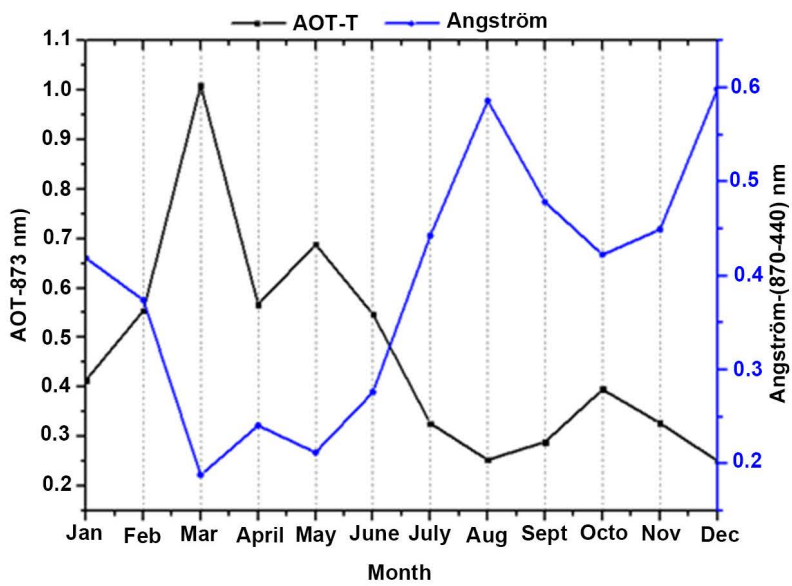

(a)

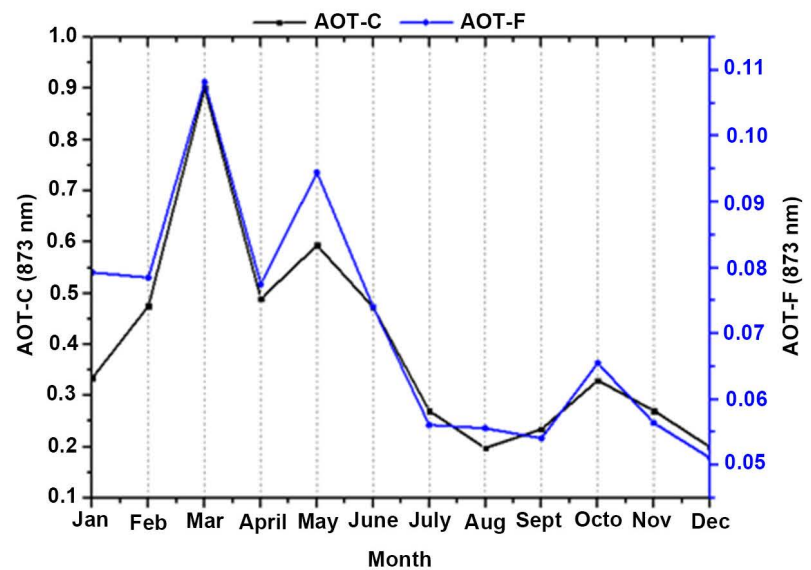

(b)

Figure 3. Monthly inter-annual averages of total optical thicknesses (AOT-T), coarse pattern (AOT-C), thin pattern (AOT-F) at $873 \mathrm{~nm}$ and of the Angstrom parameter at 440 - $870 \mathrm{~nm}$ between 1999 and 2006 of the AERONET network.

evolution of both aerosol patterns makes it possible to see that thin particles are driven by the larger ones and thus highlights the dominance of mineral dust in the aerosol type. That accounts for the plume of aerosol that affects Ouagadougou during the Harmattan. However, August and December are particular with average monthly values of the Angstrom coefficient above 0.5 (Figure 3(a)), which is typical of the thin mode of aerosols which contributes slightly in AOT shown by the minima in August. Indeed, August corresponds to heavy rains in Burkina Faso and therefore to an elimination of dusty suspensions, notably the larger ones, the remaining being particles of local pollution. The contribution of distant transport of thin particles in Summer must not be neglected [34]. On the other hand, in Winter, combustion sources are active in the sub-region, particularly in the Gulf of Guinea [8], leading therefore to a strong influence of combustion products. These particles from biomass combustions are then carried by South-West winds and get mixed with dusty particles [8] [9]. Also, the period from November to December in Burkina Faso corresponds to the end of the rainy season, leading to the development of thin desert particles from the soil recently dried up by wind erosion [17]. The secondary AOT peak noticed in October shows a possibility of dust emission during this transition period between Monsoon and Harmattan flows that occur in the Sahel. Thus, this peak can be due to local emissions because of the end of the Monsoon and the start of Harmattan.

\subsubsection{Annual Cycles of Single Scattering Albedo of Aerosols}

The single scattering albedo shows a general trend of particle scattering, clearly marked, whatever the season. This entails a low absorption of aerosols characterized by a slight presence of carbonaceous particles confirming the dominance of dust throughout the year in Burkina Faso, with the case of Ouagadougou. This more scattering character is associated with SSA values higher than 0.9, the maxima of which are encountered in Spring and in Summer, with a strong scat- 
tering in March and August (Figure 4(a)). This is specific to mainly scattering mineral dust. These values are corroborated by Mcconnell et al. [35] who also report the high level of single scattering albedo (SSA > 0.9) between March and June, period of desert dust in the Sahel. Likewise, similar values attributed to mineral dust are reported by other authors in West Africa and from Asia [36] [37]. However, SSA peaks and the Angstrom coefficient in summer clearly show a strong prevalence of dusty thin particles, particularly due to the distant transport of particles in the Saharan air layer, notably in West African regions [34]. But, the scattering minima observed in December and January may be due to a plume of aerosols composed of desert particles and combustions probably related to the intensification of the sources of combustion in Winter in the Gulf of Guinea and then transported by the winds of the southwest [8] [9] [12]. These combustions are also in agreement with the maxima of AOD which are in the south during this Winter period in Burkina Faso (Figure 2). Note that in Winter the combustion particles are drowned and dominated by desert dust due to SSA values $>0.9$ (Figure 4). In addition, aerosols in Winter at the Ouagadougou site are characterized by a mixture of large and fine particles shown by the Angstrom coefficient in January $\left(\alpha_{440-870}<0.5\right)$ and in December $\left(\alpha_{440-870}>0.5\right)$.

\subsubsection{Radiative Impact of Aerosols on the Ouagadougou Site}

In the lower layer (BOA), which is more under the influence of aerosols, the direct impact of mineral dust is clearly shown by the general cooling observed (Figure 5). This further confirms the scattering nature of the mineral particles as well as their permanent presence in the atmosphere in the Ouagadougou city. In addition, the maximum cooling is obtained in March, around $-121 \mathrm{~W} / \mathrm{m}^{2}$, confirming the dust period defined by Spring (March-April-May). However, the minimum cooling observed in Summer (June-July-August), notably in August, around $-50 \mathrm{~W} / \mathrm{m}^{2}$, is due to the impact of local carbon particles whose role is to warm up [14]. Also, this is related to the decrease of the dust in Summer in the low layer, probably because of rains and the level of moister content in the air and in soils. At the summit of the atmosphere (TOA), the radiative behavior of aerosols is similar to that of the surface, with maximum cooling in Spring and early Summer (Figure 5). This is consistent with dust distribution in the Sahel along the atmospheric column and can reach 5 to $6 \mathrm{~km}$ altitude in Spring and Summer, respectively [6] [15]. In addition, the transport of particles to the top of the atmosphere can be facilitated by the intertropical front (FIT) and then to the convective systems. Thus, in Spring and in Summer, dust in the upper troposphere is made of thin mineral particles [14], accounting for their rise to the top (TOA) characterized by their cooling effect. In addition, March is once again peculiar, with a cooling reaching $-37 \mathrm{~W} / \mathrm{m}^{2}$ while the minimum occurs in December and is around $-10 \mathrm{~W} / \mathrm{m}^{2}$ (Figure 5) revealing the effect of absorbent particles in Winters due to combustion that are very important at this time in the sub-region [2] [8]. In general, the maximum cooling at the surface and at the top of the atmosphere is characterized by the period of dust in Spring. On the 


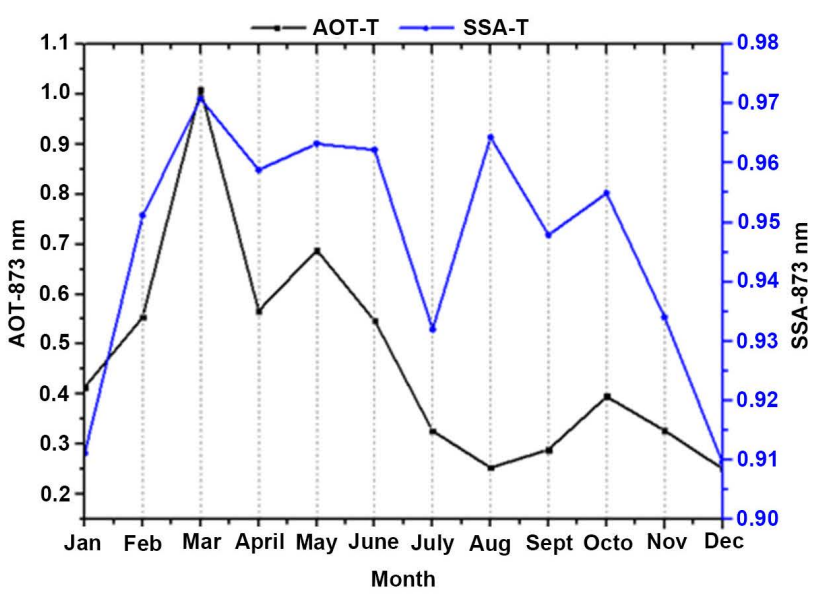

(a)

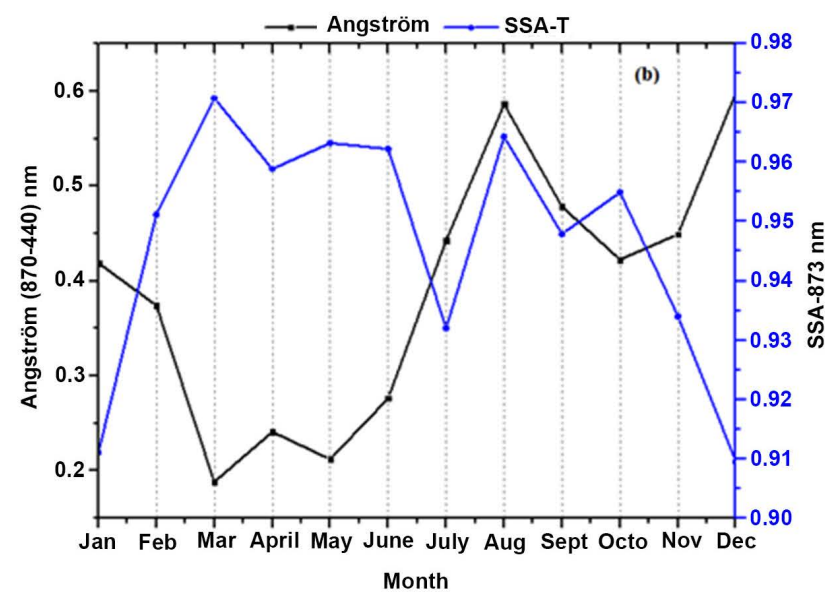

(b)

Figure 4. Monthly inter-annual averages of the optical thickness (AOT), single scattering albedo (SSA) and the Angstrom coefficient between 1999 and 2006 of the AERONET network.
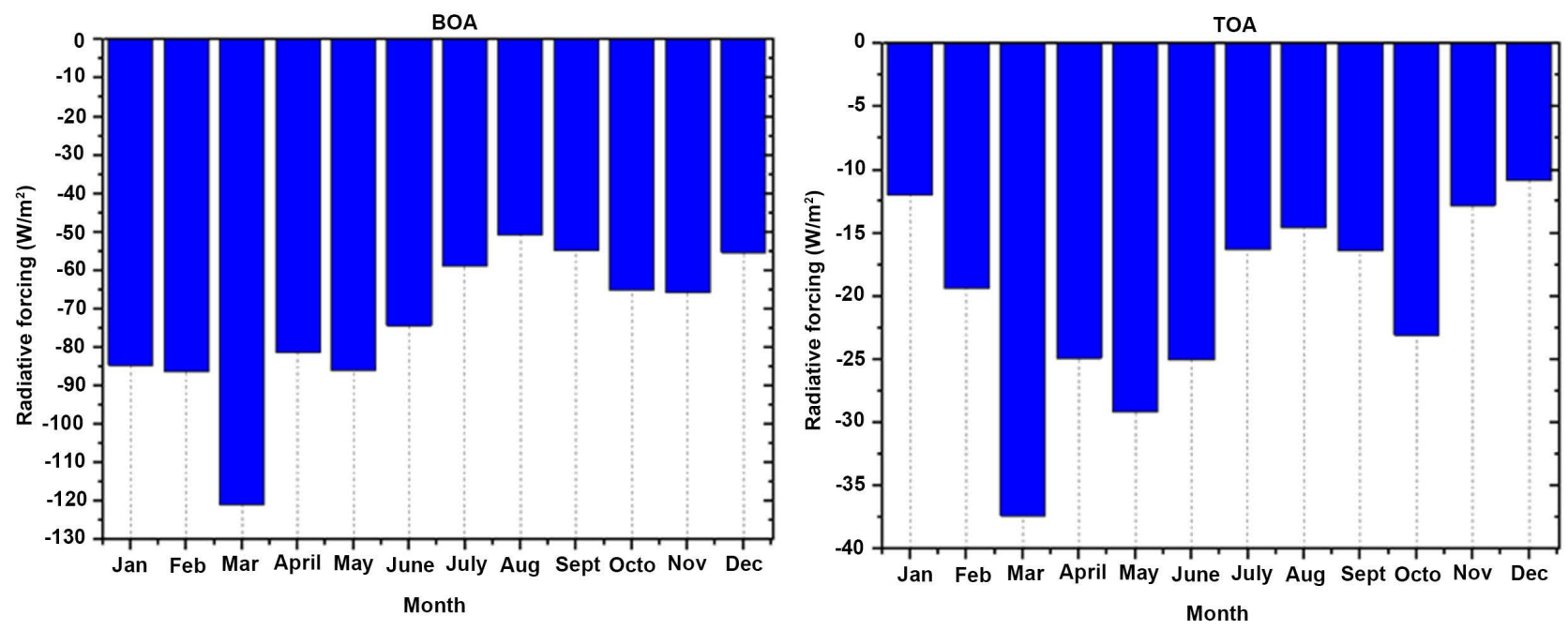

Figure 5. Histograms of the monthly inter-annual averages of aerosol radiative forcing at the bottom (BOA) and at the top (TOA) of the atmosphere reversed by AERONET in the Ouagadougou site between 1999 and 2006.

other hand, in July, August and September, the leaching of the atmosphere leads to a decrease in dust fall, reducing their cooling effect during this period. It should also be noted that this cooling decrease can be due to a suspension of more absorbent carbonaceous aerosols.

\subsubsection{Seasonal Distribution of the Aerosol Type}

Figure 6 shows the seasonal variability of the volume size distribution of aerosols on the Ouagadougou site. It shows the impact of seasonal climate dynamics on the statistical distribution of particle size. Indeed, the distribution in volume size, on the whole, shows the development of two main patterns with an intermediate one, which intensity and appearance depend on periods. Thus, from January to June and from October to December particles are characterized by a tri-modal distribution reflecting the state of mixing of aerosols noticed over 

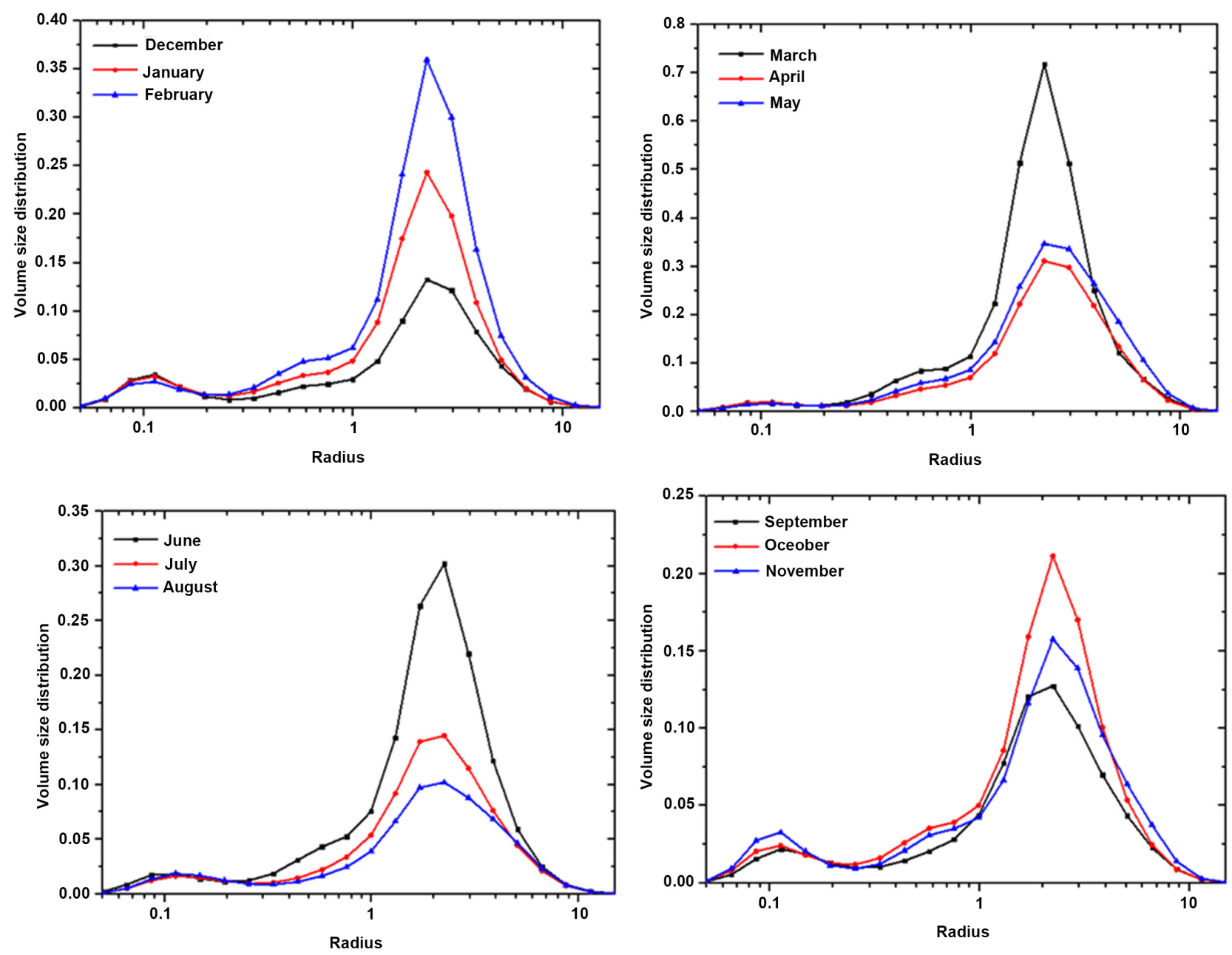

Figure 6. Monthly inter-annual averages of the volume size distribution of aerosols on the Ouagadougou site between 1999 and 2006 of the AERONET network. Radius $(\mu \mathrm{m})$ on the $\mathrm{x}$-axis and the volume size distribution $\left(\mu \mathrm{m}^{3} / \mu \mathrm{m}^{2}\right)$ on the $\mathrm{y}$-axis.

these periods characterized by the lack of rain. In July, August and September the volume size distribution of particles is rather defined by a bimodal representation. Like Korgo (2014), who reveals a presence in the thin pattern $(\mathrm{r}<1 \mu \mathrm{m})$ of a kind of carbonized particles mainly from combustion and characterized by the pattern noticed around $r=0.1 \mu \mathrm{m}$. A noticeable presence of thin desert particles was noticed, accounting for the intermediate pattern which appears around $r=0.5 \mu \mathrm{m}$. These thin particles are simply dust re-suspended locally or so-called trailing aerosols, which are thin desert particles carried along with larger ones. The coarse pattern obtained around the modal radius $r=2.24 \mu \mathrm{m}$ is dominated by more than $80 \%$ of mineral particles with a very small presence of organic particles due to combustions [17]. However, the absence of the intermediate pattern in July, August and September suggests a strong prevalence over this by local emissions of dust, which is limited by heavy rains over this period. This particle size analysis confirms the optical analysis which showed a permanent presence, all year round, of thin and large particles in different rates depending on periods. It should also be noted that February, March, April, May 


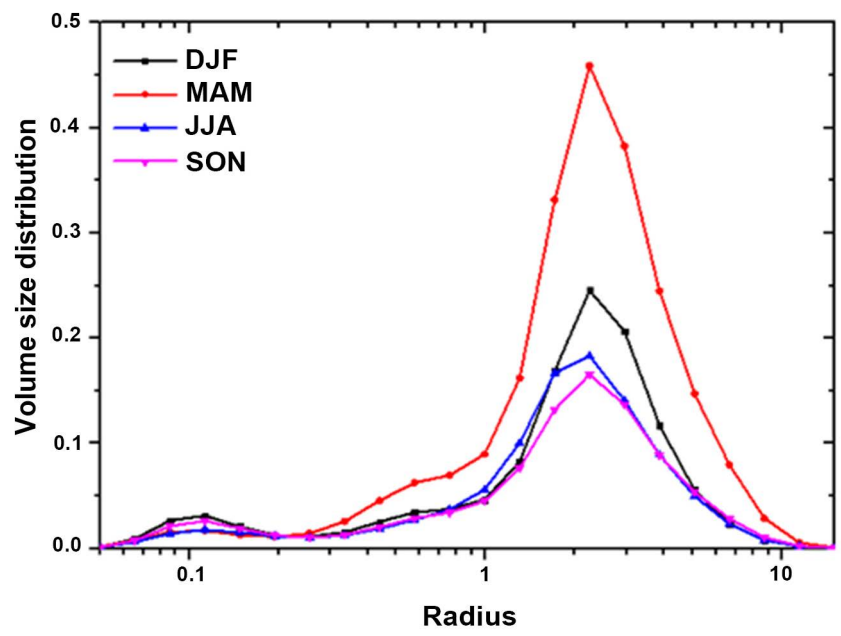

Figure 7. Inter-annual seasonal averages of the volume size distribution between 1999 and 2006 on the Ouagadougou site, with radius $(\mu \mathrm{m})$ on the $\mathrm{x}$-axis and the volume distribution $\left(\mu \mathrm{m}^{3} / \mu \mathrm{m}^{2}\right)$ on the $y$-axis.

and June dominate again, with peaks of coarse pattern that ranges between 0.3 and $0.7 \mu \mathrm{m}^{3} / \mu \mathrm{m}^{2}$.

On a seasonal basis (Figure 7), most of the dust has a size between $1 \mu \mathrm{m}$ and $10 \mu \mathrm{m}$ with a volume distribution around $0.24 \mu \mathrm{m}^{3} / \mu \mathrm{m}^{2}$ in winter (DJF), 0.45 $\mu \mathrm{m}^{3} / \mu \mathrm{m}^{2}$ in Spring (MAM), $0.18 \mu \mathrm{m}^{3} / \mu \mathrm{m}^{2}$ in Summer (JJA) and $0.16 \mu \mathrm{m}^{3} / \mu \mathrm{m}^{2}$ in Autumn (SON).

\section{Conclusion}

A climatological analysis of aerosols in the Sahelian zone, particularly in Burkina Faso, is performed based on satellite observations of the MODIS sensor and in situ measurements of the AERONET network. This makes it possible to locate the aerosols in this part of the Sahel in Spring, with a strong intensification in March revealed by the annual cycles of optical thickness and Angstrom coefficient represented for the Ouagadougou site. These particles in Burkina Faso are mostly dominated by mineral dusts characterized by their scattering nature and get cooled at the bottom and the top of the atmosphere. This is also shown by the volume size distribution where most aerosols have a size between 1 and 10 $\mu \mathrm{m}$. Thus, dust is mainly noticed in Spring while combustion aerosols much more occur in Autumn and Winter.

\section{Acknowledgements}

We thank Didier, the principal investigator of AERONET sites for the availability of AERONET data and NASA (National Aeronautics and Space Administration) for earth observations. The ISP, Uppsala University, Sweden is gratefully acknowledged for their support to project BUF01.

\section{Conflicts of Interest}

The authors declare no conflicts of interest regarding the publication of this paper. 


\section{References}

[1] Verhaege, C. (2008) Restitution de l indice de réfraction complexe et de la granulométrie $\mathrm{d}$ 'une population de particules sphériques à partir de 1 'indicatrice de diffusion de la lumière. Universite Blaise Pascal, Clermont-Ferrand.

[2] Drame, M., Bilal, B.O., Camara, M., Sambou, V. and Gaye, A. (2012) Impacts of Aerosols on Available Solar Energy at Mbour, Senegal. J. Renew. Sustain. Energy, 4, 1-13. https://doi.org/10.1063/1.3682078

[3] Pancrati, O. (2003) Teledetection de l'aerosol desertique depuis le sol par radiometrie infrarouge thermique multibande. Université des Sciences et Technologies de Lille, Villeneuve d'Ascq.

[4] Drame, M.S., Ceamanos, X., Roujean, J.L., Boone, A., Lafore, J.P., Carrer, D. and Geoffroy, O. (2015) On the Importance of Aerosol Composition for Estimating Incoming Solar Radiation: Focus on the Western African Stations of Dakar and Niamey during the Dry Season. Atmosphere (Basel), 6, 1608-1632.

https://doi.org/10.3390/atmos6111608

[5] Laurent, B., Marticorena, B., Bergametti, G. and Le, J.F. (2008) Modeling Mineral Dust Emissions from the Sahara Desert Using New Surface Properties and Soil Database. Journal of Geophysical Research, 113, 1-20.

https://doi.org/10.1029/2007JD009484

[6] Marticorena, B., Haywood, J., Coe, H., Formenti, P., Liousse, C., Mallet, M. and Pelon, J. (2011) Tropospheric Aerosols over West Africa: Highlights from the AMMA International Program. Atmospheric Science Letters, 12, 19-23.

https://doi.org/10.1002/asl.322

[7] Prospero, J.M., Ginoux, P., Torres, O., Nicholson, S.E. and Gill, T.E. (2002) Environmental Characterization of Global Sources of Atmospheric Soil Dust Identified with the Nimbus 7 Total Ozone Mapping Spectrometer (TOMS) Absorbing Aerosol Product. Reviews of Geophysics, 40, 1-31. https://doi.org/10.1029/2000RG000095

[8] Haywood, J.M., Pelon, J., Formenti, P., Bharmal, N., Brooks, M., Capes, G., Chazette, P., Chou, C., Christopher, S., Coe, H., Cuesta, J., Derimian, Y., Desboeufs, K., Greed, G., Harrison, M., Heese, B., Highwood, E.J., Johnson, B., Mallet, M., Rajot, J., Schulz, M., Slingo, A., Tanre, D. and Tulet, P. (2008) Overview of the Dust and Biomass-Burning Experiment and African Monsoon Multidisciplinary Analysis Special Observing Period-0. Journal of Geophysical Research, 113, 1-20. https://doi.org/10.1029/2008JD010077

[9] Derimian, Y., Le, J., Dubovik, O., Chiapello, I., Tanre, D., Podvin, T., Brogniez, G. and Holben, B.N. (2008) Radiative Properties of Aerosol Mixture Observed during the Dry Season 2006 over M'Bour, Senegal (African Monsoon Multidisciplinary Analysis Campaign). Journal of Geophysical Research, 113, 1-15. https://doi.org/10.1029/2008JD009904

[10] Datchoh, E.T.N., Diallo, I., Konaré, S.S., Ogunjobi, K.O., Diedhiou, A. and Doumbia, M. (2017) Dust Induced Changes on the West African Summer Monsoon Features. International Journal of Climatology, 38, 452-466. https://doi.org/10.1002/joc.5187

[11] Diokhane, A.M., Jenkins, G.S., Manga, N. and Drame, M.S. (2015) Linkages between Observed, Modeled Saharan Dust Loading and Meningitis in Senegal during 2012 and 2013. International Journal of Biometeorology, 60, 557-575. https://doi.org/10.1007/s00484-015-1051-5

[12] Drame, M.S., Camara, M. and Gaye, A.T. (2013) Intra-Seasonal Variability of Aerosols and Their Radiative Impacts on Sahel Climate during the Period 2000-2010 Using 
AERONET Data. International Journal of Geosciences, 4, 267-273. https://doi.org/10.4236/ijg.2013.41A024

[13] Nébon, B., Dramé, M.S., Bruno, K., Florent, K.P., Sall, S.M. and Joseph, D. (2018) Optical and Microphysical Analysis of Aerosols in Sahelian Zone: Case of the Ouagadougou City in Burkina Faso. Elixir International Journal, 119, 50975-50982.

[14] Korgo, B., Roger, J. and Bathiebo, J. (2013) Climatology of Air Mass Trajectories and Aerosol Optical Thickness over Ouagadougou. Global Journal of Pure and Applied Mathematics, 19, 169-181.

[15] Senghor, H., Machu, É., Hourdin, F. and Gaye, A.T. (2017) Seasonal Cycle of Desert Aerosols in Western Africa: Analysis of the Coastal Transition with Passive and Active Sensors. Atmospheric Chemistry and Physics, 17, 8395-8410. https://doi.org/10.5194/acp-17-8395-2017

[16] Drame, M., Jenkins, G.S., Camara, M. and Robjhon, M. (2011) Observations and Simulation of a Saharan Air Layer Event with a Midtropospheric Dust Layer at Dakar, Senegal, 6-7 July 2010. Journal of Geophysical Research, 116, 6-7.

[17] Korgo, B. (2014) Caractérisation optique et microphysique des aérosols atmosphériques en zone urbaine ouest africaine: Application aux calculs du forçage radiatif à Ouagadougou. Universite de Ouagadougou.

[18] Myhre, G., Grini, A., Haywood, J.M., Stordal, F., Chatenet, B., Tanre, D., Sundet, J.K. and Isaksen, I.S.A. (2003) Modeling the Radiative Impact of Mineral Dust during the Saharan Dust Experiment (SHADE) Campaign. Journal of Geophysical Research, 108, 8579. https://doi.org/10.1029/2002JD002566

[19] Camara, M., Jenkins, G. and Konare, A. (2010) Impacts of Dust on West African Climate during 2005 and 2006. Atmospheric Chemistry and Physics, Discussions, 10, 3053-3086. https://doi.org/10.5194/acpd-10-3053-2010

[20] Holben, B.N., Eck, T.F., Slutsker, I., Tanre, D., Buis, J.P., Setzer, A., Vermote, E., Reagan, J.A., Kaufman, Y.J., Nakajima, T., Lavenu, F., Jankowiak, I. and Smirnov, A. (1998) AERONET-A Federated Instrument Network and Data Archive for Aerosol Characterization. Remote Sensing of Environment, 66, 1-16. https://doi.org/10.1016/S0034-4257(98)00031-5

[21] Dubovik, O. and King, D. (2000) A Flexible Inversion Algorithm for Retrieval of Aerosol Optical Properties from Sun and Sky Radiance Measurements. Journal of Geophysical Research, 105, 9791-9806.

[22] Dubovik, O., Smirnov, A., Holben, B.N., King, M.D., Kaufman, Y.J., Eck, T.F. and Slutske, I. (2000) Accuracy Assessments of Aerosol Optical Properties Retrieved from Aerosol Robotic Network (AERONET) Sun and Sky. Journal of Geophysical Research, 105, 9791-9806. https://doi.org/10.1029/2000JD900040

[23] Dubovik, O. (2004) Optimization of Numerical Inversion in Photopolarimetric Remote Sensing. Kluwer Academic Publishers, Dordrecht, 65-106.

[24] Dubovik, O., Holben, B.N., Lapyonok, T., Sinyuk, A., Mishchenko, M.I., Yang, P. and Slutsker, I. (2002) Non-Spherical Aerosol Retrieval Method Employing Light Scattering by Spheroids. Geophysical Research Letters, 29, 3-6. https://doi.org/10.1029/2001GL014506

[25] Diarra, C. and Ba, A. (2014) Analyse des paramètres optiques des aérosols atmosphériques, de leur distribution et de leur albédo de diffusion par les mesures photométriques au Mali. Afrique Science, 10, 82-97.

[26] Levy, R.C., Remer, L.A., Mattoo, S., Vermote, E.F. and Kaufman, Y.J. (2007) Second-Generation Operational Algorithm: Retrieval of Aerosol Properties over Land from Inversion of Moderate Resolution Imaging Spectroradiometer Spectral 
Reflectance. Journal of Geophysical Research, 112. https://doi.org/10.1029/2006JD007811

[27] Kaufman, Y.J., Tanr, D., Remer, L.A., Vermote, E.F. and Chu, A. (1997) Operational Remote Sensing of Tropospheric Aerosol over Land from EOS Moderate Resolution Imaging Spectroradiometer after the Launch of MODIS the Distribution. Journal of Geophysical Research, 102, 51-67.

[28] Tanré, D., Kaufman, Y.J., Herman, M. and Mattoo, S. (1997) Remote Sensing of Aerosol Properties over Oceans Using the MODIS/EOS Spectral Radiances. Journal of Geophysical Research, 102, 16971-16988.

[29] Remer, L.A., Kaufman, Y.J., Tanré, D., Mattoo, S., Chu, D.A., Martins, J.V., Li, R.R., Ichoku, C., Levy, R.C., Kleidman, R.G., Eck, T.F., Vermote, E. and Holben, B.N. (2005) The MODIS Aerosol Algorithm, Products, and Validation. American Meteorological Society, 62, 947-973.

[30] Hsu, N.C., Tsay, S., King, M.D., Member, S. and Herman, J.R. (2004) Aerosol Properties over Bright-Reflecting Source Regions. IEEE Transactions on Geoscience and Remote Sensing, 42, 557-569. https://doi.org/10.1109/TGRS.2004.824067

[31] Kabore, B., Kam, S., Ouedraogo, G.W.P. and Bathiébo, D.J. (2017) Etude de l'évolution climatique au Burkina Faso de 1983 à 2012: Cas des villes de Bobo Dioulasso, Ouagadougou et Dori. Arabian Journal of Earth Sciences, 4, 50-59.

[32] Malavelle, F. (2011) Effets direct et semi-direct des aérosols en Afrique de l'ouest pendant la saison sèche. Université Toulouse III Paul Sabatier (UT3 Paul Sabatier).

[33] Devara, P.C.S., Saha, S.K., Raj, P.E., Sonbawne, S.M., Dani, K.K., Tiwari, K. and Maheskumar, R.S. (2005) A Four-Year Climatology of Total Column Tropical Urban Aerosol, Ozone and Water Vapor Distributions over Pune, India. Aerosol and Air Quality Research, 5, 103-114. https://doi.org/10.4209/aaqr.2005.06.0007

[34] Grey, W.M.F., North, P.R.J., Los, S.O. and Mitchell, R.M. (2006) Aerosol Optical Depth and Land Surface Reflectance from Multiangle AATSR Measurements: Global Validation and ... Aerosol Optical Depth and Land Surface Reflectance from Multiangle AATSR Measurements: Global Validation and Intersensor Comparisons. IEEE Transactions on Geoscience and Remote Sensing, 44, 2184-2197. https://doi.org/10.1109/TGRS.2006.872079

[35] Mcconnell, C.L., Highwood, E.J., Coe, H., Formenti, P., Anderson, B., Osborne, S., Nava, S., Desboeufs, K., Chen, G. and Harrison, M.A.J. (2008) Seasonal Variations of the Physical and Optical Characteristics of Saharan Dust: Results from the Dust Outflow and Deposition to the Ocean (DODO) Experiment. Journal of Geophysical Research, 113, 1-19. https://doi.org/10.1029/2007JD009606

[36] Tanre, D., Kaufman, Y.J., Holben, B.N., Chatenet, B., Karnieli, A., Lavenu, F., Blarel, L., Dubovik, O., Remer, L.A. and Smirnov, A. (2001) Climatology of Dust Aerosol Size Distribution and Optical Properties Derived from Remotely Sensed Data in the Solar Spectrum. Journal of Geophysical Research, 106, 205-218. https://doi.org/10.1029/2000JD900663

[37] Osborne, S.R., Johnson, B.T., Haywood, J.M., Baran, A.J., Harrison, M.A.J. and Mcconnell, C.L. (2008) Physical and Optical Properties of Mineral Dust Aerosol during the Dust and Biomass-Burning Experiment. Journal of Geophysical Research, 113, 1-14. https://doi.org/10.1029/2007JD009551 